\title{
STRATEGICZNE ZARZĄDZANIE ROZWOJEM GMINY
}

\section{WSTĘP}

W myśl rozwiązań ustawowych ${ }^{1}$ samorząd gminny w Polsce jest samodzielnym podmiotem gospodarujacym, dysponującym określonym zakresem swobody w decydowaniu o sobie, drodze swojego rozwoju, wspólnym majątku oraz realizacji zadań publicznych. Fundamentem ich wykonywania sa władze i administracja samorządowa oraz własne mienie i finanse. Gmina jako wspólnota samorządowa jest podstawową formą organizacyjna lokalnego życia publicznego w Polsce. Jej podstawowym zadaniem własnym jest zaspokajanie zbiorowych potrzeb wspólnoty. Innymi słowy, chodzi tu o tworzenie jak najlepszego środowiska życia mieszkańców. Stopień realizacji tego zadania w dużej mierze jest zależny od skali i tempa rozwoju lokalnego.

$\mathrm{Na}$ władzach gminy spoczywa obowiązek aktywnego sterowania procesami rozwoju lokalnego poprzez działania regulacyjne, inicjujące, organizujące i stymulujące. Wymaga to aktywności, kreatywności, innowacyjności i determinacji w działaniach władz gminy, znajomości uwarunkowań i mechanizmów jej rozwoju, wiedzy i umiejętności umożliwiających stosowanie nowoczesnych metod zarządzania i podejmowanie racjonalnych decyzji prorozwojowych oraz zastosowanie właściwych instrumentów oddziaływania na skalę i tempo tegoż rozwoju.

Gminy to złożone i trudne do zarządzania organizacje, działają w szybko zmieniających się i często nieprzewidywalnych warunkach związanych $\mathrm{z}$ ich otoczeniem. Tworzą one uwarunkowania zewnętrzne w postaci zestawu szans i zagrożeń dla ich dalszego rozwoju. Właśnie przez profesjonalne zarządzanie można zwiększyć ich zdolność adaptacyjna do tych warunków. Z drugiej strony konieczne jest całościowe i zintegrowane podejście do rozwiązywania problemów rozwojowych gminy. Dlatego dla potrzeb zarządzania ważne jest dobre rozpoznanie tych problemów, charakteru oraz siły powiązań i wzajemnych oddziaływań. Tak więc zarządzanie to z jednej strony proces podejmowania decyzji wewnątrz struktur samorządu gminnego, z drugiej zaś - działalność kierownicza ściśle powiązana z otoczeniem. Oznacza to, że zarządzanie trzeba ujmować w kontekście zmian, które obejmują głównie takie procesy, jak: globalizacja gospodarki, nasila-

${ }^{1}$ Ustawa z 8 marca 1990 r. o samorządzie gminnym, t.jedn.: Dz. U. 2013, poz. 594. 
jąca się konkurencja pomiędzy jednostkami samorządu lokalnego w skali regionalnej, krajowej i międzynarodowej, decentralizacja władzy publicznej, wprowadzanie nowych rozwiązań proefektywnościowych, członkostwo Polski w Unii Europejskiej.

We współczesnej metodyce zarządzania rozwojem organizacji zaleca się stosowanie koncepcji zarządzania strategicznego, które winno być silnie powiązane $\mathrm{z}$ działaniami marketingowymi. W myśl tej koncepcji zarządzanie strategiczne jest przemyślanym, perspektywicznie zaplanowanym, skutecznie zorganizowanym i efektywnie realizowanym oraz stale kontrolowanym procesem formułowania i wdrażania strategii rozwoju organizacji. Koncepcja ta skupia uwagę zarządzających organizacją na jak najlepszym wykorzystaniu własnych walorów i zasobów w długookresowej perspektywie. Chodzi tu o rozwój własnego (endogenicznego) potencjału, który w konsekwencji określa poziom atrakcyjności lokalizacyjnej i konkurencyjności organizacji $\mathrm{w}$ otoczeniu. Z kolei działania marketingowe wspomagają skuteczną i efektywną realizację ustaleń strategicznych. Podstawowym zadaniem marketingu jest rozpoznanie potrzeb, wymagań i oczekiwań potencjalnych klientów, a następnie dostarczenie produktów, które będa dla nich źródłem korzyści (użyteczności) w sposób bardziej skuteczny i efektywny niż konkurenci. Ważne miejsce winny zajmować także problemy aktywnego kreowania pozytywnego wizerunku organizacji oraz zwiększania jej pozycji konkurencyjnej w otoczeniu. W Polsce coraz wyraźniej kształtuje się rynek jednostek samorządu gminnego, który staje się coraz bardziej konkurencyjny. Jest to konkurencja o nowych mieszkańców, inwestorów zewnętrznych i środki finansowe, czyli w rezultacie o wymierne korzyści dla społeczności gminnej. Od tego zależy w dużej mierze rozwój gospodarczy, który jest wyznacznikiem realnych możliwości zaspokajania zbiorowych potrzeb mieszkańców. Rywalizowanie gmin o te korzyści to wyraz podejścia rynkowego.

Celem opracowania jest przedstawienie ogólnych założeń strategicznego podejścia do zarządzania rozwojem gminy, które winno być silnie powiązane $\mathrm{z}$ działaniami marketingowymi. Zarządzanie strategiczne i marketing terytorialny mają wiele elementów wspólnych, elementy wyróżniające zaś uzupełniaja się, wzbogacając oba podejścia. Ich połączenie przyczyniać się może do powstania efektu synergii w postaci wartości dodanej ponad prosta sumę osiagniętych rezultatów, uzyskanego w wyniku współoddziaływania komplementarnych wobec siebie metod zarządzania.

Niniejsze opracowanie zostało przygotowane za pomocą następujących metod badawczych: analizy i syntezy literatury przedmiotu, metody obserwacji i metody komparatywnej w odniesieniu do stosowanych metod zarzadzania w polskich gminach oraz metody projektowania, której wynikiem jest autorskie spojrzenie na problemy zarządzania rozwojem gminy².

${ }^{2}$ Ponadto treści zawarte $\mathrm{w}$ opracowaniu są rezultatem wieloletnich związków autora z praktyką gospodarczą jako konsultanta metodycznego i eksperta oraz twórcy kilkudziesięciu strategii rozwoju, wieloletnich planów finansowych i inwestycyjnych miast, gmin wiejskich i powiatów. 


\section{ROLA WKADZ SAMORZĄDOWYCH W PROCESACH ROZWOJU GMINY}

Rozwój gminy ma charakter wieloaspektowy. Składa się on bowiem z wielu zdarzeń, zjawisk i procesów zaliczanych do różnych sfer (dziedzin) życia społeczności lokalnej. Oznacza to, że nie powinny być one rozpatrywane oddzielnie, samoistnie, lecz przeciwnie - właśnie w ścisłych współzależnościach, jakie między nimi zachodza, majacych charakter przyczynowo-skutkowy, przestrzenny bądź strukturalno-funkcjonalny. Stąd też rozwój gminy winien dokonywać się równocześnie i harmonijnie w sferze: społecznej, kulturowej, gospodarczej, przestrzennej i przyrodniczej. Jest on niezbędnym warunkiem wzrostu:

a) atrakcyjności lokalizacyjnej (inwestycyjnej) oraz rangi gminy w otoczeniu, a w konsekwencji wzrostu liczby mieszkańców, podmiotów gospodarczych i turystów,

b) zatrudnienia i spadku rozmiarów bezrobocia,

c) dochodów indywidualnych mieszkańców i dochodów budżetu gminy, a w konsekwencji wzrostu jakości życia mieszkańców wskutek coraz lepszego zaspokajania ich zbiorowych potrzeb.

W rozwoju lokalnym uczestniczy zbiór współzależnych podmiotów gospodarujaccych, działajaccych na terenie określonej gminy, z których każdy spełnia określone funkcje i dąży do realizacji własnych - często partykularnych - celów. Sa to: gospodarstwa domowe i gospodarstwa rolne, jednostki gospodarcze (produkcyjno-usługowe), różnego rodzaju instytucje, organizacje pozarządowe oraz gminne władze samorządowe. Podmioty te tworzą lokalny system gospodarowania. Działania tych podmiotów powinny się w różny sposób uzupełniać, aby w sumie składały się na rozwój gminy. Jednak wielopodmiotowość uczestników oraz wielość i różnorodność zachodzacych procesów i interakcji stwarza sytuacje, w których interesy poszczególnych podmiotów gospodarujących są często sprzeczne lub konfliktogenne.

W związku z tym szczególna rola w lokalnym systemie gospodarowania przypada władzom gminnym, które są podsystemem sterującym w tym systemie. Ich zadaniem jest w taki sposób wpływać na procesy rozwojowe, aby przebiegały one nie tylko w pożądanych dla całej gminy kierunkach, lecz także powodowały one jak najmniej sprzeczności i konfliktów przy optymalnym wykorzystaniu lokalnych zasobów (ludzkich, rzeczowych, finansowych, przestrzennych, przyrodniczych). Jednak ich rola nie powinna ograniczać się wyłącznie do sfery regulacji, lecz obejmować również wpływ na kształt sfery realnej, zwłaszcza poprzez:

a) świadczenie usług administracyjnych, społecznych i technicznych,

b) inicjowanie, organizowanie, wspieranie i stymulowanie rozwoju gospodarczego,

c) racjonalne zagospodarowanie przestrzeni, ochronę zasobów środowiska przyrodniczego i dziedzictwa kulturowego,

d) kształtowanie jak najlepszego wizerunku gminy w otoczeniu. 
Działania $\mathrm{w}$ tym zakresie można określić mianem interwencjonizmu samorządowego ${ }^{3}$, analogicznie do interwencjonizmu państwowego. Wraz z decentralizacją władzy i zastępowania rozwoju gałęziowo-branżowego nową logiką rozwoju terytorialnego samorząd gminny stał się podmiotem ingerencji w procesy rynkowe, a także ich aktywnym uczestnikiem. Tak więc samorząd gminny jako faktyczny gospodarz określonego terytorium ponosi zatem odpowiedzialność za organizację, strukturę, funkcjonowanie i rozwój lokalnego środowiska życia mieszkańców gminy ${ }^{4}$.

\section{METODY ZARZĄDZANIA ROZWOJEM W POLSKICH GMINACH}

Poziom zaspokojenia potrzeb mieszkańców gminy zdeterminowany jest skalą i tempem procesów rozwojowych. Sukcesy gmin na tym polu wiążą się ściśle ze sprawnością i skutecznością zarządzania. Opierając się na definicji zarządzania sformułowanej przez W. M. Gaczek ${ }^{5}$, zarządzanie rozwojem gminy można określić jako dążenie do zapewnienia osiagnięcia pożądanego poziomu rozwoju lokalnego, który dokonuje się w warunkach gry rynkowej, gdzie warunkami brzegowymi sa z jednej strony ograniczoność własnych zasobów i niepewność warunków gospodarowania, z drugiej zaś - możliwości, czyli różne sposoby wykorzystywania własnych zasobów i szans tkwiących w otoczeniu. Innymi słowy, przez zarządzanie rozwojem gminy należy rozumieć zorganizowane, systematyczne i kompleksowe oddziaływanie (bezpośrednie i pośrednie) władz gminy na społeczność lokalna, gospodarkę, przestrzeń, środowisko przyrodnicze w celu tworzenia optymalnych warunków stymulujacych wykorzystanie szans i ograniczenie zagrożeń rozwoju lokalnego.

Wieloletnia praktyczna obserwacja polskich gmin i sposobów podejścia ich władz do rozwiązywania problemów rozwojowych stanowiła podstawę do wyodrębnienia - przez autora - kilku stosowanych metod (sposobów) zarządzania. Metody te zostały uszeregowane od najmniej do najbardziej pożądanych, jeśli chodzi o skuteczne i efektywne kształtowanie procesów rozwojowych w gminie ${ }^{6}$.

\footnotetext{
${ }^{3}$ A. Sztando, Lokalny interwencjonizm samorzadowy, czyli ksztattowanie gminnego rozwoju gospodarczego, „Studia Regionalne i Lokalne” 2000, $\mathrm{nr}$ 1, s. 79-89; idem, Interwencjonizm samorzadowy - obszary i instrumenty oddziatywania samorzadu terytorialnego na gospodarkę lokalna, w: Gospodarka lokalna w teorii i w praktyce, Prace Naukowe Akademii Ekonomicznej im. O. Langego we Wrocławiu, nr 785, Wrocław 1998, s. 125-134.

4 J. J. Parysek, Podstawy gospodarki lokalnej, WN UAM, Poznań 1997, s. 15-17; Z. Gilowska, System ekonomiczny samorzadu terytorialnego w Polsce, Municipium, Warszawa 1998, s. 26-45; E. J. Blakely, Planning Local Economic Development - Theory and Practice, Sage Library of Social Research, t. 168, Sage Publications, Newbury Park 1989, s. 57-72.

${ }^{5}$ W. M. Gaczek, Zarzqdzanie w gospodarce przestrzennej, Oficyna Wydawnicza Branta, Bydgoszcz-Poznań 2003, s. 16.

${ }^{6}$ M. Ziółkowski, Przemiany $w$ podejściu do zarzqdzania rozwojem $w$ samorzqdzie gminnym, w: R. Bartkowiak, J. Ostaszewski (red.), Dorobek ekonomii, finansów i nauk o zarzqdzaniu oraz jego praktyczne wykorzystanie na przełomie XX $i$ XXI wieku, Oficyna Wydawnicza SGH w Warszawie, Warszawa 2012, s. 419-430.
} 
Metoda 1. „Działanie od budżetu do budżetu”, czyli bieżące administrowanie polega na koncentrowaniu się władz gminnych, pod wpływem istniejących trudności, na sprawach doraźnych i fragmentarycznych. Działają one zachowawczo, intuicyjnie, brak sukcesów zaś usprawiedliwiają niekorzystnymi okolicznościami zewnętrznymi. Podstawą ich działania są coroczne budżety i roczne plany operacyjne - budżet gminy staje się celem samym w sobie, a nie środkiem realizacji celów. Takie podejście prowadzi niestety do rozwiązań przejściowych (tymczasowych), połowicznych i fasadowych, które potem ulegają utrwaleniu, władze gminy zaś często występują w roli „straży pożarnej”, czyli podejmuja działania dopiero w sytuacji pojawienia się określonego problemu czy też zdarzenia. Jest to podejście oparte na filozofii „leczenia już zaistniałych negatywnych skutków", a nie na filozofii działań prewencyjnych, czyli „przeciwdziałania przyczynom ich powstawania”. Brak tutaj podejścia całościowego, kompleksowego i długookresowego oraz przyczynowo-skutkowego, czyli analizy wpływu dzisiaj podjętych decyzji na przyszłe losy gminy. Decyzje podejmowane przez władze gminy są w dużym stopniu oparte na metodach prób i błędów, które liczą na szczęśliwy przypadek, oraz są wynikiem, corocznie z trudem osiaganego, kompromisu. Podstawa „bieżącego administrowania” sa takie maksymy, jak: „funkcjonujemy z dnia na dzień i jakoś to będzie” oraz „trzeba żyć dniem codziennym, nie myśleć zbyt wiele o przyszłości, bo i tak będzie inaczej, niż przewidywaliśmy”. Jest to pasywne (bierne) podejście do kształtowania procesów rozwojowych gminy. Doświadczenia polskie wskazuja, że tak rozumiane „bieżące administrowanie” jest przyczyna powstawania szeregu konfliktów i napięć wśród członków władz gminy. Ich działania koncentruja się bowiem na corocznej walce o środki budżetowe na realizację preferowanych przez siebie zadań. Decyzje dotyczące skali i kierunków wydatkowania środków finansowych z budżetów gminnych (zwłaszcza inwestycyjnych) są w tej sytuacji podporządkowane przede wszystkim uzyskaniu bieżącego kompromisu. Nie wynikają one niestety z ustaleń o charakterze długookresowym. Jest to jednym $\mathrm{z}$ istotnych powodów nieracjonalnego wydatkowania tych środków. Stosowanie tej metody rozwiązywania problemów nie przyczynia się również do realizacji konstytucyjnej zasady rozwoju zrównoważonego, a także zasad: racjonalnego gospodarowania i partycypacji społecznej. Ta metoda rozwiązywania problemów rozwojowych jest - zdaniem autora - stosowana nadal przez ok. $25 \%$ ogółu polskich gmin ${ }^{7}$, zwłaszcza małych wiejskich gminach, położonych peryferyjnie względem głównych szlaków komunikacyjnych i dużych miast.

Metoda 2. „Działanie kadencyjne” to metoda, która koncentruje się na rozwiązywaniu problemów rozwojowych gminy w horyzoncie jednej (czteroletniej) kadencji władz gminy, w myśl wyznawanej przez jej członków zasady: „nasza kadencja jest najważniejsza, kolejne kadencje sa zbyt odległe, aby o nich myśleć". Władze gminy sa świadome faktu, że ich działania winny być uprzednio przemyślane i zaplanowane w dłuższym okresie niż jeden rok ka-

7 Obecnie w Polskie funkcjonuje 2479 gmin, w tym: 306 miejskich, 597 miejsko-wiejskich i 1576 wiejskich. 
lendarzowy, lecz nie w dłuższym niż cztery lata. Tworzą więc na początku kadencji programy, czy też plany działania, z reguły bardzo ambitne co do liczby celów i zadań realizacyjnych, a także możliwości ich sfinansowania z własnych środków (budżetu gminy). Chcąc zrealizować jak najwięcej zadań, aby wykazać się przed wyborcami, niedobory własnych środków finansowych uzupełniają kredytami. Ta sytuacja ma miejsce zwłaszcza w trzecim i czwartym roku trwania kadencji. Skutkuje to nadmiernym w stosunku do możliwości finansowych zadłużaniem się gminy i prowadzi do nadmiernego obciążenia jej budżetu spłatami rat kredytów i odsetek w następnej kadencji lub kadencjach władz gminy. Wpływać to będzie negatywnie na możliwości rozwiązywania problemów rozwojowych w przyszłości, najpierw bowiem trzeba będzie spłacać wcześniej zaciąnnięte zobowiązania. W skrajnym przypadku w kolejnej kadencji nie będzie żadnych wolnych środków, które można by przeznaczyć na inwestycje rozwojowe, gdyż najpierw trzeba spłacać kredyty oraz finansować bieżące zadania wynikające z przepisów prawa. Takie podejście władz gminy można określić mianem: „po nas choćby potop”. Kredytowanie przedsięwzięć rozwojowych nie jest złą metodą ich finansowania, trzeba jednak pamiętać, aby mieć na uwadze zdolność kredytową gminy i starać się nadmiernie nie obciążać budżetu gminy spłatami rat i odsetek w przyszłych kadencjach. Ta metoda rozwiązywania problemów rozwojowych jest - zdaniem autora - stosowana przez ok. 20\% ogółu polskich gmin. W tym przypadku trudno jest wskazać typ gmin, w których stosowano lub stosuje się tę metodę rozwiązywania problemów rozwojowych. Można jedynie powiedzieć, że w większym stopniu dotyczy to po pierwsze gmin charakteryzujących się znacznymi niedoborami w zakresie infrastruktury technicznej i społecznej, których władze są na tyle ambitnie, że chcą w stosunkowo krótkim czasie (jednej kadencji) nadrobić te zaległości, po drugie gmin, których poprzednie władze nie były zbyt aktywne na polu kształtowania procesów rozwojowych (,nasi poprzednicy byli bierni i nieaktywni, to teraz my pokażemy, jak można szybko rozwiązywać problemy").

Metoda 3. „Działanie życzeniowe” jest metodą rozwiązywania problemów polegająca na tym, że władze gminy dostrzegaja konieczność kształtowania procesów rozwojowych w długim okresie (kilku następnych kadencjach). Opracowuja one stosowne dokumenty (strategie rozwoju, programy i plany działania). Jednak ich podstawowym mankamentem jest to, że zawierają zbyt wiele celów i przedsięwzięć realizacyjnych w stosunku do możliwości ich sfinansowania zarówno z własnych środków (budżetu gminy), jak i zewnętrznych źródeł finansowania (znane są autorowi przypadki miast, w których koszt przewidzianych do realizacji zadań inwestycyjnych kształtował się na poziomie 5-7 budżetów). W związku z tym te dokumenty mają w dużym stopniu charakter „koncertu życzeń”, z góry bowiem wiadomo, że część zamierzeń nie będzie mogła być zrealizowana. Ta metoda powoduje także, że mieszkańcy postrzegają działania władz gminy jako w znacznej części obietnice bez pokrycia. Ta metoda rozwiązywania problemów rozwojowych jest - zdaniem autora - stosowana przez ok. 20\% ogółu polskich gmin. W tym przypadku także trudno jest wskazać typ gmin, w których stosowano lub stosuje się tę metodę. 
Można jedynie powiedzieć, że skutkuje ona istotnymi zmianami w składzie władz gminy w kolejnych wyborach samorządowych. Dotyczy to zarówno radnych, jak i wójtów/burmistrzów/prezydentów miast.

Metoda 4. „Działanie strategiczne” jest metodą zarządzania, polegająca na kształtowaniu procesów rozwojowych gminy i rozwiązywaniu zdefiniowanych problemów w długim horyzoncie czasu (kilkunastoletnia perspektywa). Działania w tym względzie nie są prostą kompilacją rocznych czy też kadencyjnych (czteroletnich) planów działania, znajdujących swe odzwierciedlenie w corocznie uchwalanych budżetach, lecz wynikają z ustaleń perspektywicznych, a co najważniejsze - są skorelowane z możliwościami ich sfinansowania zarówno ze środków własnych, jak i zewnętrznych. Ta metoda zarządzania nastawiona jest na opracowywanie i realizowanie skutecznych strategii rozwoju i wynikających z nich programów i planów działania ${ }^{8}$. Jest ona ukierunkowana przede wszystkim na maksymalne wykorzystanie endogenicznych czynników rozwoju (zasoby ludzkie, finansowe, rzeczowe, ekologiczne i przestrzenne) i potencjału miejscowych podmiotów gospodarujacych, oczywiście z uwzględnieniem uwarunkowań tkwiących w jej otoczeniu. Ta metoda rozwiąywania problemów rozwojowych jest - zdaniem autora - stosowana przez ok. $25 \%$ ogółu polskich gmin, wśród których znajdują się zarówno małe gminy wiejskiej, jak i duże miasta. Kryterium rozstrzygającym nie jest tu wielkość, typ czy też lokalizacja gminy, lecz stan wiedzy członków władz danej gminy na temat korzyści ze stosowania zarządzania strategicznego w rozwiązywaniu problemów rozwojowych i determinacja w jego praktycznym stosowaniu.

Metoda 5. „Działanie strategiczno-marketingowe”. Jest to najbardziej pożądana metoda zarządzania rozwojem gminy w warunkach gospodarki rynkowej i narastającej konkurencji międzygminnej przede wszystkim o kapitał (prywatny i publiczny), tylko bowiem kompleksowe (zintegrowane) podejście do zagadnień z tym związanych daje większą gwarancję odniesienia sukcesu na tym polu.

\section{ISTOTA DZIAŁAŃ STRATEGICZNO-MARKETINGOWYCH}

Zarządzanie strategiczne i marketing terytorialny mają wiele elementów wspólnych, elementy wyróżniające zaś uzupełniają się wzajemnie. Ich połączenie przyczynia się do powstania efektu synergii, co w konsekwencji wpływa na zwiększenie siły oddziaływania tegoż zarządzania na skalę i dynamikę

8 E. Wojciechowski, Zarzqdzanie w samorzadzie terytorialnym, Difin, Warszawa 2003, s. 1134; M. Ziółkowski, M. Goleń, Zarządzanie strategiczne rozwojem lokalnym, w: H. Sochacka-Krysiak (red.), Zarzadzanie gospodarka $i$ finansami gminy, wyd. 2 uzupełnione i zaktualizowane, Oficyna Wydawnicza SGH w Warszawie, Warszawa 2006, s. 70-76; M. Ziółkowski, Zarzqdzanie strategiczne w polskim samorzadzie terytorialnym, w: A. Zalewski (red.), Nowe zarzadzanie publiczne w polskim samorzqdzie terytorialnym, wyd. 2 zmienione i rozszerzone, Oficyna Wydawnicza SGH w Warszawie, Warszawa 2007, s. 103-107. 
procesów rozwojowych. Elementami wspólnymi obu ujęć są: cele działania, pojęcie gminy jako podmiotu sterującego procesami rozwoju lokalnego, długookresowa perspektywa działania, etapy zarządzania (planowanie, wdrażanie i kontrola realizacji). Z kolei elementami je różniącymi sa: obszary działania i stosowane instrumenty.

Ogólnie rzecz ujmując, zarządzanie strategiczne jest w głównej mierze skierowane na stałe podnoszenie atrakcyjności lokalizacyjnej (inwestycyjnej) gminy ${ }^{9}$ poprzez tworzenie jak najlepszej oferty produktowej, tj. produktów o cechach (właściwościach) najbardziej adekwatnych do potrzeb i oczekiwań potencjalnych klientów. Chodzi tu o tworzenie jak najlepszych warunków zamieszkiwania, pracy, obsługi i wypoczynku mieszkańców, prowadzenia działalności gospodarczej i pobytu turystów (obecnych i potencjalnych). Jest ono ukierunkowane przede wszystkim na maksymalne wykorzystanie endogenicznych czynników rozwoju gminy (zasoby ludzkie, rzeczowe, finansowe, przestrzenne, przyrodnicze) oraz potencjału miejscowych podmiotów gospodarujących, oczywiście z uwzględnieniem uwarunkowań tkwiących w jej otoczeniu. Atrakcyjność lokalizacyjna (inwestycyjna) jest czynnikiem tworzacym podstawy do konkurencji ${ }^{10}$ gminy i determinujacym jej konkurencyjnośćc ${ }^{11}$.

Z kolei marketing terytorialny jest wynikiem przeniesienia i adaptacji koncepcji marketingu w sektorze prywatnym do sektora publicznego. Jest to także konsekwencja odpowiedzi na wyzwania globalizacji gospodarki, narastajacej presji konkurencyjnej na jakość otoczenia terytorialno-społeczno-gospodarczego, w której działaja prywatni producenci dóbr. Według A. Szromnika „marketing terytorialny jest celową i systematyczną działalnością administracji samorządowej, zmierzająca poprzez procesy wymiany i oddziaływania do rozpoznania, kształtowania i zaspokojenia potrzeb oraz pragnień społeczności lokalnej”12. Jest też przez niego definiowany ,jako rynkowa koncepcja zarządzania jednostką osadnicza - jako zarządzanie zmierzające do zaspokojenia potrzeb i pragnień mieszkańców"13. T. Markowski definiuje marketing teryto-

${ }^{9}$ Można ją rozpatrywać z dwóch punktów widzenia. Po pierwsze, z punktu widzenia gminy atrakcyjność lokalizacyjna (inwestycyjna) to walory, zasoby, cechy (właściwości), atrybuty danego obszaru (określa się je mianem czynników lokalizacji) - tworzą one zbiór korzyści (użyteczności) możliwy do osiagnięcia przez potencjalnych klientów w trakcie zamieszkania, prowadzenia działalności gospodarczej i czasowego pobytu. Po drugie, z punktu widzenia klienta atrakcyjność lokalizacyjna (inwestycyjna) gminy jest kategorią względna, postrzeganą i ocenianą na tle innych, na podstawie relacji korzyści (użyteczności) do kosztów (uciążliwości) zamieszkania, prowadzenia działalności gospodarczej i czasowego pobytu w danej gminie.

${ }^{10}$ Konkurencja to rywalizacja, współzawodnictwo między poszczególnymi gminami w oferowaniu klientom korzystniejszej oferty produktowej (np. z punktu widzenia warunków użytkowania, kosztów zakupu, cech/atrybutów, czy też jakości) oraz pozyskiwaniu kapitału finansowego (prywatnego i publicznego).

${ }^{11}$ Konkurencyjność to możliwości, umiejętności, zdolności gminy do skutecznego rywalizowania (współzawodnictwa) z innymi gminami wyrażająca się w praktyce umiejętnościa „przyciagania” na swój teren nowych klientów (mieszkańców, podmiotów gospodarczych i turystów).

${ }^{12}$ A. Szromnik, Marketing komunalny, „Samorząd Terytorialny” 1996, nr 3, s. 6.

${ }^{13}$ Idem, Marketing terytorialny - miasto i region na rynku, wyd. 4 poszerzone, Oficyna a Wolters Kluwer business, Warszaw 2012, s. 29. 
rialny jako „pewien system aktywności umożliwiający korzystną wymianę dóbr w mieście oraz w jego otoczeniu w celu zaspokojenia potrzeb mieszkańców”14. Natomiast M. Florek definiuje marketing terytorialny jako proces, w którym lokalne działania nakierowane sa na efektywne społeczne i ekonomiczne funkcjonowanie terytorium zgodnie $\mathrm{z}$ wytyczonymi celami ${ }^{15}$.

Marketing gminy oznacza celową i kompleksową działalność władz i administracji samorządowej, zmierzającą do rozpoznawania, kształtowania i zaspokajania potrzeb społeczności lokalnej, kształtowania pozytywnego wizerunku gminy oraz podnoszenia jej konkurencyjności w otoczeniu. Winien to być proces, w którym uczestniczy, w porozumieniu i we współpracy, wiele podmiotów zarówno publicznych, jak i prywatnych. W praktyce proces ten dokonuje się przez opracowanie i wdrożenie strategii marketingowej gminy. Przedmiotem tak rozumianego marketingu gminy sa:

a) usługi władz i administracji gminnej, gminnych jednostek organizacyjnych na rzecz społeczności lokalnej (usługi w sferze obsługi administracyjnej, infrastruktury społecznej i technicznej),

b) walory, zasoby, cechy/atrybuty gminy stanowiace jej atuty rozwojowe (społeczne, gospodarcze, ekologiczne, przestrzenne, infrastrukturalne, kulturowe), nieruchomości do zagospodarowania i wykorzystania, znaczące przedsiębiorstwa zlokalizowane na terenie gminy oraz jej wizerunek - określa się je mianem potencjału lokalizacyjnego

Zarządzanie marketingowe jest w głównej mierze nastawione na długookresowe działania zmierzajace do:

a) zdefiniowania potrzeb docelowych grup klientów oraz dostarczeniu im pożądanego produktu w sposób bardziej efektywny i wydajny niż konkurenci - orientacja na klientów oznacza, że ponieważ pragnie pozyskać i utrzymać klientów przy sobie systematycznie, dokonuje się identyfikacji i prognozowania ich potrzeb,

b) kreowania potrzeb klientów zgodnie z własnymi interesami jednostki terytorialnej na podstawie istniejaccych własnych, unikatowych produktów,

c) kształtowania jak najbardziej pozytywnego wizerunku gminy,

d) zwiększania pozycji konkurencyjnej gminy w otoczeniu.

Nawiąując do powyższych stwierdzeń, proponuję następująca definicję strategiczno-marketingowego podejścia do zarządzania rozwojem gminy: sa to celowe, zintegrowane i długookresowe działania na rzecz wzrostu atrakcyjności lokalizacyjnej (inwestycyjnej) i konkurencyjności oraz jak najlepszego wizerunku gminy przy wykorzystaniu endogenicznych czynników rozwoju (zasobów i walorów gminy) i czynników egzogenicznych (tkwiących w otoczeniu gminy) zgodnie z oczekiwaniami i potrzebami społeczności lokalnej oraz zasadami ${ }^{16}$ : racjonalnego gospodarowania, rozwoju zrównoważonego i partycypacji społecznej.

14 T. Markowski, Zarzadzanie rozwojem miasta, WN PWN, Warszawa 1999, s. 214.

15 M. Florek, Podstawy marketingu terytorialnego, Wyd. AEP, Poznań 2006, s. 17.

16 Zasada racjonalnego gospodarowania polega na „maksymalizacji efektów z wydatkowanych nakładów lub minimalizacji nakładów na uzyskanie założonych efektów”. Zasada rozwoju zrównoważonego oznacza „powszechne uznawanie nadrzędności wymogów ekologicznych w sto- 
Strategiczno-marketingowe zarządzanie rozwojem gminy można także zdefiniować jako: zdolność (umiejętność) skutecznego i efektywnego rozwiązywania problemów poprzez formułowanie, a następnie realizowanie ustaleń strategii rozwoju oraz innych studiów, programów i planów działania danej gminy. Na ogólną zdolność do rozwiązywania problemów składa się szereg umiejętności cząstkowych, a mianowicie zdolność do:

a) identyfikowania problemów,

b) wariantowania sposobów rozwiązania problemu i wyboru rozwiązania optymalnego,

c) wytyczania realnych celów rozwoju i formułowania przedsięwzięć realizacyjnych oraz wyboru priorytetów rozwojowych,

d) absorpcji wiedzy i innowacji,

e) racjonalnego gospodarowania środkami finansowymi,

f) współdziałania na zasadach partnerstwa ze wszystkimi zainteresowanymi podmiotami,

g) działania w warunkach nieprzewidywalności zdarzeń i procesów w otoczeniu,

h) działania w warunkach ryzyka i niepewności,

i) pozyskiwania zewnętrznych środków finansowych,

j) konkurencji z innymi gminami,

k) kreowania pozytywnego wizerunku gminy.

W strategiczno-marketingowych działaniach gminę traktuje się jako system o złożonych relacjach przyczynowo-skutkowych jej podsystemów: społecznego, gospodarczego, przestrzennego, przyrodniczego i kulturowego oraz jednostkę ściśle powiązaną z otoczeniem. Takie podejście sprzyja silniejszej koordynacji działań podmiotów gospodarujacych funkcjonujacych na terenie gminy, eliminuje lub minimalizuje negatywne skutki różnego typu konfliktów, ułatwia pokonywanie różnego typu barier rozwojowych. Jednocześnie pomaga precyzyjnie dostosować działania rozwojowe do lokalnych uwarunkowań, zwłaszcza finansowych. Pozwala także na pełne wykorzystanie potencjału (intelektualnego i organizacyjnego) władz i pracowników administracji samorządowej oraz gminnych jednostek organizacyjnych. Sprzyja także włączaniu mieszkańców, organizacji społecznych, biznesu, uczelni wyższych oraz innych instytucji i organizacji w procesy planowania i realizacji działań prorozwojowych.

sunku do procesów rozwoju społeczno-gospodarczego i zagospodarowania przestrzeni gminy". Innymi słowy, dalszy rozwój gminy nie może dokonywać się „kosztem” środowiska przyrodniczego, a więc musi respektować oszczędna produkcję i konsumpcję oraz gospodarkę terenami, a także uwzględniać przyszłościowe konsekwencje ekologiczne podejmowanych dzisiaj decyzji. Zachowanie istniejących zasobów ekologicznych oraz dobry stan czystości środowiska przyrodniczego jest jednym z podstawowych warunków podnoszenia jakości środowiska życia mieszkańców gminy. Zasada partycypacji społecznej, czyli uspołecznienia procesu zarządzania rozwojem gminy, oznacza włączanie w prace planistyczne, realizacyjne i kontrolne jak najszerszego grona mieszkańców i reprezentantów społeczności lokalnej (organizacji pozarządowych) oraz lokalnych przedsiębiorców. 
Podstawowym zadaniem w ramach strategiczno-marketingowego podejścia do rozwoju gminy jest znalezienie, a następnie wybór optymalnych przy danych uwarunkowaniach wewnętrznych i zewnętrznych - działań realizacyjnych prowadzących do stałego zwiększania atrakcyjności lokalizacyjnej (inwestycyjnej) i konkurencyjności gminy oraz zapewnienia warunków do rozwoju zrównoważonego, a w konsekwencji jak najlepszego zaspokajania zbiorowych potrzeb mieszkańców. Fundamentalne znaczenie dla skuteczności i efektywności tego sposobu działania ma tzw. programowanie strategiczno-marketingowe, będące podstawą aktywności władz gminnych w zakresie tworzenia i realizacji określonych dokumentów programowych. Do podstawowych instrumentów zaliczyć można: strategie rozwoju, studia i plany zagospodarowania przestrzennego, wieloletnie plany inwestycyjne i finansowe, strategie (plany) marketingowe oraz inne programy/plany sektorowe i branżowe (np. rozwoju oświaty, pomocy społecznej, ochrony środowiska, rozwoju układu drogowo-ulicznego, komunikacji miejskiej). Działania strategiczno-marketingowe na rzecz rozwoju gminy prezentuje schemat 1 .

\section{Schemat 1}

Działania strategiczno-marketingowe na rzecz rozwoju gminy
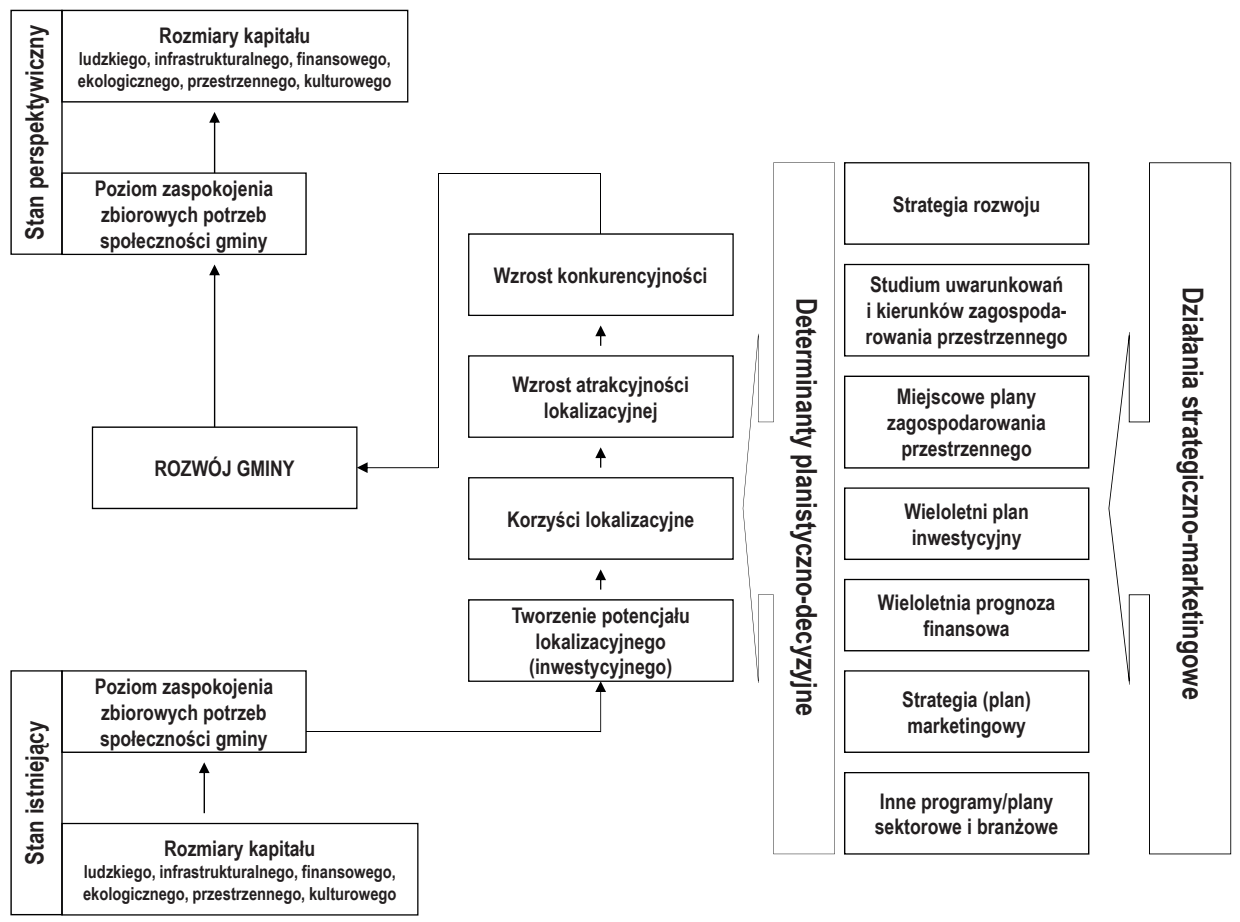

Źródło: opracowanie własne. 


\section{PODSTAWOWE CECHY DZIALAŃ STRATEGICZNO-MARKETINGOWYCH}

Podstawowymi cechami tak rozumianego podejścia do zarządzania rozwojem gminy sa:

a) orientacja na potrzeby społeczności lokalnej, czyli rozpoznanie oraz zaspokojenie ilościowych potrzeb i podnoszenie jakości świadczonych usług komunalnych (społecznych, technicznych i administracyjnych);

b) kompleksowość w podejściu do problemów rozwoju, czyli współzależne ujmowanie wszystkich sfer (dziedzin) funkcjonowania gminy (gospodarczej, społecznej, przestrzennej, ekologicznej, kulturowej, finansowej i inwestycyjnej);

c) jak najlepsze wykorzystanie endogenicznych czynników i zasobów dla zdynamizowania procesów rozwoju;

d) orientacja na przyszłość, czyli rozwiązywanie dzisiejszych problemów przez pryzmat przyszłości, a także uznanie, że postęp, innowacyjność i konkurencyjność jako wyraz rozwoju gminy są najważniejsze dla jakości środowiska życia mieszkańców;

e) orientacja na otoczenie gminy, czyli maksymalne wykorzystywanie szans i przeciwdziałanie zagrożeniom;

f) orientacja na wyniki, czyli osiaganie celów rozwoju przez sukcesywna, skuteczną i efektywną realizację - zaplanowanych wcześniej - konkretnych zadań realizacyjnych;

g) orientacja na zasoby i walory gminy - intelektualne, rzeczowe, finansowe, ekologiczne, przestrzenne i kulturowe, czyli maksymalne ich spożytkowanie dla dalszego rozwoju;

h) orientacja na kreowanie pozytywnego wizerunku gminy, czyli eksponowanie „dóbr gminnych” (np. usługi komunalne, atrakcyjność turystyczna, wartości środowiska przyrodniczego, nieruchomości, oferty lokalizacyjne, zasoby i walory dziedzictwa kulturowego) z punktu widzenia pełnionych przez nie funkcji wobec konsumentów tych dóbr (obecnych i potencjalnych);

i) orientacja na podnoszenie konkurencyjności gminy w otoczeniu regionalnych, krajowym i międzynarodowym.

Podmiotem tak rozumianego podejścia do zarządzania rozwojem gminy jest lokalna wspólnota samorządowa działająca poprzez swoje ciała przedstawicielskie i administrację samorządowa, posiadająca ${ }^{17}$ :

- po pierwsze - autonomię decyzyjna, rozumianą jako swoboda decyzji i wyboru autonomicznych wartości i celów rozwoju oraz tworzenia skutecznych programów ich realizacji,

- po drugie - kreatywność, rozumianą jako zdolność władzy samorządowej do formułowania i rozwiązywania problemów, twórczą umiejętność wykorzystywania metod i technik planowania oraz ich adaptacji do zmieniających się warunków zewnętrznych,

- po trzecie - umiejętność współdziałania ze społecznością lokalną przy rozwiązywaniu problemów gminy.

${ }_{17}$ M. Ziółkowski, Zarzadzanie strategiczne w polskim, s. 104. 
Ponadto, decyzje dotyczące skali i zakresu działań prorozwojowych powinny być oparte na analizie wielokryterialnej, której podstawą jest myślenie systemowe, obejmujace następująca sekwencję działań:

a) badanie struktury problemu decyzyjnego, czyli poszczególnych jego elementów składowych, wzajemnych interakcji między nimi oraz związków zachodzacych między danym problemem a realizowanymi celami oraz otoczeniem (bliższym i dalszym),

b) rozpatrywanie przewidywanej decyzji nie tylko z punktu widzenia danego problemu decyzyjnego, ale także w kontekście wszystkich realizowanych celów i zadań,

c) przewidywanie następstw (pozytywnych i negatywnych) podejmowanej decyzji wraz z uwzględnieniem wszystkich ograniczeń i barier występujących w rzeczywistości, w tym zwłaszcza finansowych.

Fundamentalne znaczenie przypisywane jest zatem tym cechom podmiotu zarządzającego, które decydują o zdolnościach do inicjowania procesów endogenicznego rozwoju gminy i ich kojarzenia z procesami rozwoju wymuszanymi przez otoczenie.

\section{ETAPY DZIAŁAŃ STRATEGICZNO-MARKETINGOWYCH}

Należy wyróżnić następujące etapy działań strategiczno-marketingowych na rzecz rozwoju gminy: diagnozowanie i analizowanie potrzeb społeczno-gospodarczych, planowanie, wdrażanie oraz monitoring i kontrola.

\section{Diagnozowanie i analizowanie potrzeb}

Jest to pierwszy etap procesu strategiczno-marketingowego zarządzania rozwojem gminy, zarówno w długim, jak i w krótkim okresie. Etap ten polega na rozpoznaniu i analizie potrzeb zgłaszanych przez członków społeczności lokalnej oraz potencjalnych mieszkańców, inwestorów i turystów. Diagnozowania wymaga także sytuacja społeczno-gospodarcza i ekologiczno-przestrzenna gminy, w tym jej zasoby i walory, a także otoczenie. Możliwości rozwoju i zaspokajania potrzeb są zależne od uwarunkowań wewnętrznych i zewnętrznych. W pierwszym przypadku diagnoza stanu ma pokazać, jakie zjawiska i procesy zachodzace w gminie sa jej atutami i sprzyjają rozwojowi, a jakie sa słabościami i będą miały negatywny wpływ na skalę i tempo procesów rozwojowych w przyszłości. W drugim przypadku analiza ma pokazać, jakie zjawiska i procesy zachodzace $\mathrm{w}$ otoczeniu gminy będą szansami, a jakie będą zagrożenia dalszego rozwoju gminy.

\section{Planowanie}

Planowanie polega na formułowaniu celów i sposobów ich osiagnięcia. $\mathrm{Na}$ tym etapie należy uwzględnić aktualny stopień zaspokojenia potrzeb społecznych oraz przewidzieć dynamikę ich zmian w perspektywie bliższej i dalszej. 
Długookresowym celom strategicznym, które mają charakter kierunkowy, podporządkowane winny być średnio- i krótkookresowe cele operacyjne. Te z kolei przekładają się na konkretne projekty realizacyjne. Efektem finalnym tej fazy zarządzania jest opracowanie dokumentów programowych - strategii rozwoju, studiów i planów zagospodarowania przestrzennego, wieloletnich planów inwestycyjnych i finansowych, strategii (planu) marketingowego oraz innych programów/planów sektorowo-branżowych.

\section{Wdrażanie}

Etap ten polega na realizacji ustaleń strategii rozwoju oraz innych dokumentów programowych poprzez konkretne projekty (zadania realizacyjne). $\mathrm{Na}$ tym etapie powinno dojść do zbudowania odpowiedniej struktury organizacyjnej administracji gminnej. Kluczowa jest tutaj rola organu wykonawczego gminy w postaci wójta/burmistrza/prezydenta. Od jego zaangażowania, doświadczenia, znajomości specyfiki funkcjonowania gminy, wiedzy z zakresu zarządzania strategicznego i marketingu terytorialnego, kompetentnego zespołu współpracowników oraz umiejętności organizowania, przewodzenia i komunikowania się zależy wypracowanie właściwej kultury organizacyjnej administracji samorządowej oraz skuteczność i efektywność jej działania. W procesie realizacji przyjętych celów należy w jak najszerszym zakresie wykorzystywać metodę zarządzania projektami, która jest jednocześnie wyzwaniem i sprawdzianem dla efektywności struktury i jakości kultury organizacyjnej administracji gminnej.

\section{Monitoring i kontrola}

Monitoring jest de facto weryfikacją zgodności uzyskiwanych efektów z założonymi celami. Jego istota jest wyciaganie właściwych wniosków z tego, co zostało, a co nie zostało zrobione, a także modyfikowanie dalszych poczynań w taki sposób, aby osiagnaçć zakładane cele. Oceny realizacji przyjętych ustaleń winny być dokonywane na bieżąco oraz ex post z uwzględnieniem trzech kryteriów, tj.: skuteczności, co pozwala określić, czy cele rozwojowe określone na etapie ich planowania zostały osiagnięte; efektywności, co pozwala porównać poniesione nakłady na realizację przyjętych ustaleń z uzyskanymi efektami oraz korzystności, co pozwala określić saldo skutków pozytywnych i negatywnych realizacji przyjętych ustaleń dla mieszkańców gminy. Powinien być to proces ciagły, obejmujący w szczególności następujące działania:

a) zbieranie i interpretowanie (oceny) danych opisujacych postępy i efekty realizowanych projektów,

b) bieżący nadzór, kontrolę i ocenę realizacji poszczególnych projektów,

c) wczesne diagnozowanie trudności mogących mieć niekorzystny wpływ na realizowane poszczególnych projektów, zwłaszcza na ich terminowość i ostateczne koszty realizacji, 
d) korygowanie i modyfikowanie projektów, jeśli nie ma szans i możliwości ich wykonania,

e) weryfikację zgodności założonych planów finansowych z faktyczną ich realizacja,

f) ocenę efektywności wykorzystania środków finansowych pozostających w dyspozycji budżetu gminy i aktualizację prognoz finansowych,

g) aktualizację i uzupełnianie zapisów dokumentów programowych w zależności od pojawiających się zewnętrznych i wewnętrznych merytorycznych przyczyn,

h) sporządzanie zbiorczego raportu z realizacji ustaleń dokumentów programowych (np. corocznie albo raz na dwa lata).

Monitoring ma więc za zadanie szybko wykrywać tendencje i zdarzenia mogace mieć negatywny wpływ na skalę i tempo realizacji celów rozwoju i projektów w niej zapisanych. W zależności od wyniku tej oceny sformułowane wnioski powinny sygnalizować potrzebę intensyfikacji bądź ograniczenia podejmowanych kierunków działań, aktualizacji i modyfikacji zapisów dokumentów programowych oraz kontynuacji dotychczas realizowanych projektów. Winien on być prowadzony zarówno w zakresie rzeczowym, jak i finansowym. Monitoring rzeczowy winien obejmować skwantyfikowane dane obrazujące postęp w realizacji projektów oraz umożliwiać oceny ich wykonania w odniesieniu do przyjętych celów rozwoju. Natomiast monitoring finansowy winien obejmować ocenę racjonalności i sprawności wydatkowania środków finansowych (własnych i zewnętrznych) na realizacje projektów.

$\mathrm{Na}$ tym etapie znacząca rolę odgrywają badania prowadzone wśród mieszkańców na temat ilości i jakości świadczonych usług komunalnych. Celem badań jest pokazanie stopnia i poziomu odczuwalnych efektów realizowanych celów i wynikających z nich projektów realizacyjnych.

\section{KOMUNIKACJA SPOLECZNA}

Elementem łączącym poszczególne etapy działań strategiczno-marketingowych na rzecz rozwoju gminy jest komunikacja społeczna, która jest podsystemem zarządzania. Bez skutecznego systemu komunikacji społecznej (wewnętrznej i zewnętrznej) nie może być mowy o skutecznym systemie zarządzania gmina. Każda gmina musi wypracować system komunikacji społecznej, czyli system pozyskiwania i przekazywania informacji. Na system ten składają się ludzie i metody oraz sprzęt do pozyskiwania, gromadzenia, porządkowania, analizowania, oceny i przekazywania informacji. System gminnej komunikacji społecznej to z jednej strony władze gminy, pracownicy samorządowi i gminne jednostki organizacyjne, a z drugiej - przedstawiciele grup docelowych, tj. grupa docelowa wewnętrzna - mieszkańcy, przedsiębiorcy $\mathrm{i}$ inne podmioty zlokalizowane na terenie gminy oraz grupa docelowa zewnętrzna - potencjalni mieszkańcy, inwestorzy, turyści, politycy, administracja regionalna i administracja rządowa. Sprawność i efektywność dzia- 
łania systemu gminnej komunikacji społecznej zależy zarówno od zaangażowania, umiejętności, sposobu pozyskiwania, analizowania i oceny informacji z jednostek gminnych i od przedstawicieli grup docelowych, jak i od umiejętności doboru form i środków przekazywania informacji wspomnianym wyżej grupom.

Komunikacja społeczna władz gminy z grupami docelowymi odgrywa ważną rolę na wszystkich etapach strategiczno-marketingowego zarządzania rozwojem gminy. Tym bardziej że nie są to niezależne od siebie, lecz ściśle powiązane ze sobą, powtarzające się i przenikające się etapy jednego spójnego procesu. Na etapie diagnozowania i analizowania zasadniczą rolę odgrywa badanie potrzeb i oczekiwań społecznych oraz stopnia ich zaspokojenia, a także ilości i jakości świadczonych usług komunalnych. Pozyskane od mieszkańców opinie powinny być następnie, na etapie planowania, punktem wyjścia do formułowania celów rozwojowych i projektów realizacyjnych. Cykliczne badanie opinii grup docelowych pozwoli na etapie wdrażania na bieżące monitorowanie realizowanych projektów (zadań realizacyjnych), a na etapie kontrolowania - na podejmowanie odpowiednich działań korygujących. Badanie grup docelowych może być realizowane w różnorodny sposób, od analizy tekstów prasowych i innych przekazów medialnych, przez aktywną obsługę zażaleń obywatelskich i interwencji, telefoniczne przyjmowanie opinii, analizę jakości decyzji administracyjnych i audyt pracy poszczególnych jednostek organizacyjnych, aż po uzyskiwanie informacji za pomoca pogłębionych wywiadów środowiskowych i sondaży opiniii ${ }^{18}$. Do pozyskiwania informacji od mieszkańców, jako szczególnej grupy celowej, służą formy bezpośrednie i pośrednie, z takimi środkami, jak: codzienne kontakty pracowników administracji gminy z interesantami, spotkania członków władz gminy z mieszkańcami, korespondencja drukowana i elektroniczna, badania ankietowe.

\section{ZAKOŃCZENIE}

Odniesienie sukcesu w rozwoju gminy w największym stopniu zdeterminowane jest umiejętnością dostosowania się do nowych wyzwań, zmian i procesów zachodzących w bliższym i dalszym otoczeniu. Wymagają one, aby gmina wykreowała własny mechanizm dostosowawczy, zapewniający rozwój, a w konsekwencji poprawę środowiska życia mieszkańców. Skuteczne działania w tym względzie są w dużym stopniu funkcją jakości zarządzania, czyli umiejętności rozwiązywania problemów przez jej władze. Jakość zarządzania rzutuje również na jej atrakcyjność lokalizacyjną (inwestycyjna) dla nowych mieszkańców, podmiotów gospodarczych i pobytu turystów, a także wizerunek i konkurencyjność w otoczeniu. W tym celu gminy rozwijaja - obok inwestycji

${ }_{18}$ A. Wiktorowska (red.), Komunikacja i wspótpraca sektorów w gminie, LGPP, Municipium, Warszawa 2000, s. 21. 
infrastrukturalnych i w ochronie środowiska oraz przekształceń w zagospodarowaniu przestrzennym - różnorodne formy przedsięwzięć marketingowych. Jakość zarządzania ułatwia także dostęp do różnych zewnętrznych środków finansowych, w tym zwłaszcza zagranicznych (np. środki pomocowe Unii Europejskiej), najważniejszą bowiem kwestią w tym względzie jest umiejętność właściwego sformułowania i merytorycznego uzasadnienia wniosku o współfinansowanie konkretnego zadania inwestycyjnego.

Zaprezentowana $\mathrm{w}$ niniejszym opracowaniu koncepcja działań strategiczno-marketingowych stanowi, zdaniem autora, dobra podstawę do skutecznego i efektywnego rozwiązywania problemów rozwojowych. Jest to koncepcja, która umożliwia całościowe i kompleksowe podejście do problemów zaspokajania zbiorowych potrzeb mieszkańców gminy, wzrostu jej atrakcyjności osadniczej, inwestycyjnej i turystycznej oraz wzrostu konkurencyjności gminy w otoczeniu regionalnym, krajowym i międzynarodowym. Umożliwia także realizację fundamentalnych zasad: racjonalnego gospodarowania, rozwoju zrównoważonego i partycypacji społecznej. Koncepcja ta umożliwia:

- po pierwsze - zdiagnozowanie potrzeb społeczności lokalnej (obecnej i potencjalnej) i na tej podstawie określenie skutecznych i efektywnych sposobów ich zaspokojenia w oparciu o posiadane walory i zasoby, czyli potencjał lokalizacyjny;

- po drugie - funkcjonowanie władz gminy i pracowników samorządowych w sytuacji niepewności oraz nieprzewidywalności szeregu zjawisk i procesów w otoczeniu, a także traktowanie wynikajacego z nich ryzyka działania jako stałego elementu procesu zarządzania gmina;

- po trzecie - zwiększenie zdolności adaptacyjnej gminy do szybko zmieniającej się rzeczywistości;

- po czwarte - prowadzenie aktywnej działalności marketingowej w odniesieniu do własnych walorów i zasobów (marketing oferowanych produktów terytorialnych) oraz aktywnych działań na rzecz stałej poprawy wizerunku i pozycji konkurencyjnej gminy w otoczeniu.

W wyniku takiego podejścia powinien powstać efekt synergii, czyli efekt w postaci wartości dodanej ponad prostą sumę osiagniętych rezultatów, uzyskany w wyniku komplementarności obu metod zarządzania. Należy traktować go co prawda jako pożądany, dodatkowo zaistniały rezultat tej komplementarności, lecz trzeba mieć świadomość, że efekt synergii nie zawsze jest możliwy do osiąnięcia, a ponadto w wielu przypadkach jest trudny do zmierzenia. Dla przykładu do podstawowych efektów synergii zaliczyć można:

- na etapie planowania i realizacji działań prorozwojowych - precyzyjniejsze określenie potrzeb społeczno-gospodarczych, celów rozwoju, priorytetów i projektów realizacyjnych, lepsze dostosowanie działań prorozwojowych do lokalnych uwarunkowań, zwłaszcza finansowych, racjonalizacja wydatków budżetowych, skuteczna koordynacja i terminowość realizacji poszczególnych działań, skracanie cykli inwestycyjnych, bardziej skoordynowana i dokładnie adresowana działalność marketingowa - w tym przypadku możemy mówić o synergii potencjalnej, która może być efektem komplementarności obu metod zarządzania; 
- po zakończeniu działań prorozwojowych - oszczędność środków budżetowych, lepszy wizerunek i wyższa pozycja konkurencyjna gminy w otoczeniu, lepsza koordynacja działań podmiotów gospodarujacych funkcjonujacych na terenie gminy, bardziej aktywna współpraca z mieszkańcami, przedsiębiorcami i organizacjami pozarządowymi - w tym przypadku możemy mówić o synergii faktycznej, która jest efektem komplementarności obu metod zarządzania.

W ostatecznym rozrachunku podstawowym efektem synergii wynikającym z komplementarności zarządzania strategicznego i marketingu terytorialnego będzie lub może być skuteczniejsze i efektywniejsze zaspokojenie zbiorowych potrzeb mieszkańców gminy.

Systematyczne i długookresowe działania strategiczno-marketingowe na rzecz rozwoju gminy wciąż nie należą do powszechnego kanonu działania władz gminnych w Polsce. Podstawowa trudność budowania klimatu dla tego typu działań wynika z mentalności i nawyków oraz braku wiedzy wśród członków władz oraz pracowników samorządowych. Pojęcie „zarządzanie strategiczno-marketingowe” jest kojarzone głównie ze sfera gospodarki i przedsiębiorstwami. W wielu przypadkach instrumenty zarządzania strategiczno-marketingowego uznawane są za konieczność wynikająca z przejściowej mody, za formalny wymóg (np. przy ubieganiu się o środki pomocowe UE), niewnoszący istotnych zmian do praktyki funkcjonowania gminy. Do długookresowego i kompleksowego zarządzania gminą zniechęca wybieranie radnych i wójtów/burmistrzów/prezydentów na okres czteroletniej kadencji, co sprzyja myśleniu w perspektywie co najwyżej średniookresowej. Zasadniczym jednak problemem jest nadal brak dostatecznej wiedzy wśród członków władz polskich gmin oraz pracowników samorządowych o korzyściach dla społeczności lokalnej, jakie wynikają z praktycznego stosowania strategiczno-marketingowego zarządzania gmina. W tej sytuacji rzadko stosuje się w gminach podejście strategiczno-marketingowe, będące podstawa kształtowania kompleksowego ich rozwoju. Częściej władze gmin wykorzystują poszczególne elementy tej koncepcji, np. posiadanie strategii rozwoju gminy bez programów i planów realizacyjnych, opracowywanie wieloletniego planu inwestycyjnego bez jednoczesnego sporządzania wieloletniego planu finansowego, brak programów promocji gminy lub ich złe przygotowanie (np. nie posiadają one zdefiniowanego odbiorcy, stąd ich ustalenia nie wiadomo, do kogo są adresowane).

Zaprezentowana koncepcja działań strategiczno-marketingowych na rzecz rozwoju gminy nie jest z pewnością jakimś cudownym lekarstwem na wszelkie bolączki polskich gmin. Jest jednak próbą długookresowego i kompleksowego spojrzenia na problemy rozwoju gminy oraz wskazania narzędzi ułatwiających ich skuteczne i efektywne przezwyciężanie. 
STRATEGIC MANAGEMENT OF LOCAL (GMINA) DEVELOPMENT

\section{Sum mary}

The article presents the essential features of strategic-marketing management as a basis for the effective and efficient control of the processes of local (gmina) government development, and in consequence the best way of satisfying the collective needs of inhabitants. The author indicates the role of local government in the regulation, creation and stimulation of local development and moreover the need for a complex approach to local development problems. The evolution of the approach to local development management in Polish local (gmina) authority areas is also presented. Against this background the paper presents the essence, concepts, elementary features and successive stages of the management of strategic-marketing development in local authority areas.

Outcomes of the analysis show that achieving success in activities for local government development depends significantly on the efficient and effective use of management methods. One of these methods, according to the author, is the strategic-marketing method. As a result of this approach the synergy effect should be generated, that is an effect of value added beyond the simple sum of results obtained as a consequence of complementary management methods. This approach shows that priorities, goals and implementation tasks are determined comprehensively, honestly and are compatible with a realistic possibility of execution and financing. In consequence the effectiveness of implementation activities is an enhanced, which translates into a higher level of satisfaction of the collective needs of the inhabitants, increase in the attractiveness of the location, an improvement of its image and increasing competitiveness of the urban communes in the surrounding area. 
